https://doi.org/10.52058/2786-4952-2022-1(6)-339-350

Танасійчук Юлія Миколаївна доктор філософії, старший викладач кафедри медико-біологічних основ фізичної культури, Уманський державний педагогічний університет імені Павла Тичини, вул. Садова 2, м. Умань, 20300, тел.: (047) 443-45-82, https://orcid.org/0000-0001-7772-1509

Бойко Юлія Степанівна кандидат педагогічних наук, доцент, доцент кафедри медико-біологічних основ фізичної культури, Уманський державний педагогічний університет імені Павла Тичини, вул. Садова 2, м. Умань, 20300, тел.: (047) 443-45-82, https://orcid.org/0000-0001-8554-9737

Соколенко Людмила Степанівна кандидат педагогічних наук, доцент, професор кафедри медико-біологічних основ фізичної культури, Уманський державний педагогічний університет імені Павла Тичини, вул. Садова 2, м. Умань, 20300, https://orcid.org/0000-0002-1285-1596

\title{
ПРОБЛЕМИ ФОРМУВАННЯ КУЛЬТУРИ ЗДОРОВОГО СПОСОБУ ЖИТТЯ СТУДЕНТІВ ЗАКЛАДІВ ВИЩОЇ ОСВІТИ
}

Анотація. Представлено критичний аналіз проблематики залучення студентів закладів вищої освіти до ведення здорового способу життя. Мета: визначення напрямків формування культури здорового способу життя студентів вищих навальних закладів. Методи: анкетування; теоретичні методи педагогічного дослідження. Учасники: студенти різних курсів навчання (дівчата та хлопці) закладів вищої освіти України 2-4 курсів (n = 150). Результати та обговорення. Формування здоров'язбережувального середовища закладу вищої освіти сприяє створенню умов раціонального засвоєння студентами ведення здорового способу життя. Наразі зниження рівня здоров'я студентської молоді пов'язане як 3 їх «позитивним» відношенням до шкідливих звичок, так і частковим, обмеженим популярними поглядами, уявленням про сутність та необхідність здорового способу життя. Дані тенденції $є$ відображенням зміни суспільної формації та значним інформаційним тиском життєвого простору сучасного українського студента. Студентам важко самотужки протистояти стрес-факторам навчального процесу, а також негативному інформаційному змісту, що разом з відсутністю цілеспрямованої діяльності викладачів та адміністрації навчального закладу, для забезпечення тих, хто навчається знаннями з ведення здорового способу життя, знецінює поняття особистісного здоров'я. Висновки. Таким чином, проблеми формування культури здорового способу життя студентів потребує комплексної стратегії у рамках створення такого середовища закладу вищої 
освіти, яке сприятиме підвищенню престижності здорового способу життя. Дана стратегія має враховувати формування особистісної культури здоров'я всіх учасників освітнього процесу. Результатом має стати формування дієвих засобів-орієнтирів на формування здорового способу життя студентів в період занурення у навчальних процес 3 подальшою можливістю екстраполяції на поведінку поза межами навчального закладу.

Ключові слова: фізична культура особистості, здоров'язбережувальна компетенція, освітній простір, здоровий спосіб життя, студентська молодь.

Tanasiichuk Iuliia Mykolaivna $\mathrm{PhD}$, lecturer of Medical and Biological Fundamentals of Physical Culture Department of Pavlo Tychyna Uman State Pedagogical University, Sadova St., 2, Uman, 20300, tel.: (047) 443-45-82, https://orcid.org/0000-0001-7772-1509

Boyko Julia Stepanivna $\mathrm{PhD}$ in Education, associate professor of Medical and Biological Fundamentals of Physical Culture Department of Pavlo Tychyna Uman State Pedagogical University, Sadova St., 2, Uman, 20300, tel.: (047) 443-45-82, https://orcid.org/0000-0001-8554-9737

Sokolenko Lyudmyla Stepanivna Ph.D.(Pedagogy), assistant professor Professor of Medical and Biological Fundamentals of Physical Culture Department of Pavlo Tychyna Uman State Pedagogical University, Sadova St., 2, Uman, 20300, tel.: (047) 443-45-82, https://orcid.org/0000-0002-1285-1596

\section{PROBLEMS OF FORMATION OF CULTURE OF HEALTHY LIFESTYLE OF STUDENTS OF HIGHER EDUCATIONAL INSTITUTIONS}

Abstract. A critical analysis of the issue of involving students of higher educational institutions in leading a healthy lifestyle is presented. Purpose: to determine the directions of formation of a culture of healthy lifestyle of students of higher bulk institutions. Methods: questionnaires; theoretical methods of pedagogical research. Participants: students of different courses (girls and boys) of higher educational institutions of Ukraine 2-4 courses $(\mathrm{n}=150)$. Results and discussion. The formation of a healthy environment of higher education allows to create conditions for the rational assimilation of students to lead a healthy lifestyle. Currently, the decline in the health of young students is due to their «positive» attitude to bad habits, as well as partial, limited to popular views, ideas about the nature and necessity of a healthy lifestyle. These trends reflect changes in social formation and significant information pressure on the living space of modern Ukrainian students. It is difficult for students to cope alone with the stressors of the educational process, as well as negative information content, which, together with the lack of purposeful activities of teachers and administration of the school, to 
provide students with knowledge of healthy living, devalues personal health. Conclusions. Thus, the problems of forming a culture of healthy lifestyle of students requires a comprehensive strategy in the framework of creating an environment of higher education, which will increase the prestige of a healthy lifestyle. This strategy should consider the formation of personal health culture of all participants in the educational process. The result should be the formation of effective tools for guiding the formation of a healthy lifestyle of students during the period of immersion in the educational process with the subsequent possibility of extrapolation to behavior outside the institution.

Keywords: physical culture of personality, health-preserving competence, educational space, healthy lifestyle, students.

Постановка проблеми. Формування світоглядових основ молодого покоління неможливе без урахування складової здорового способу життя (ЗСЖ). Аналізоване поняття розширює уявлення молоді не тільки відносно особистісного значення здоров'я, але також й розуміння неабиякої важливості суспільного здоров'я як складового чинника якості життя. Визначення життєвих пріоритетів найбільше загострюється в період навчання. Саме ті нечисленні роки, які проводить молода людина у навчальному закладі характеризуються експресією думок та ідей які складають основу подальшої життєвої позиції та орієнтацій щодо провадження діяльності в рамках здоров'язбережувальної суспільної парадигми. Тому значуще значення має характер освітнього середовища навчального закладу в контексті засвоєння студентом здоров'язбережувальної компетенції як основи ведення здорового способу життя протягом тривалого часу.

Сучасна трансформація суспільства у світі відображається на тенденціях, які формують стиль життя молодих українців. Зі свого боку, у царині вищої освіти, спостерігається активний пошук та поєднання різних освітніх парадигм, з метою підвищення якості підготовки майбутніх фахівців. Втім, посилення студентоцентричних тенденцій у освітньому середовищі певною мірою стосується процесу навчання (аудиторної роботи), натомість питання забезпечення розвитку навичок ЗСЖ не знаходить достатнього відображення у процесах реформування системи вищої освіти України [8].

Так само, з року в рік збільшується кількість наукових публікацій, де містяться дані про згубну роль стресових факторів, які супроводжують навчальний процес сучасних студентів вищих навчальних закладів. Відповідь молодого організму на психо-фізіологічні перенавантаження навчального процесу ускладняється у зв'язку зі значної соціальною мобільністю молоді, особливо осіб, які навчаються на перших двох курсах. Зокрема, періоди сесій відзначаються посиленням дії стресогенних факторів. Відтак, молодий організм, який, з одного боку, має значні адаптаційні потенції, з іншого боку, стикається 3 перенавантаженнями і неспецифічними для його попередньої діяльності стресфакторами, що призводять до значних порушень енергобалансу. 
Перенесення навантажень та тиску освітнього середовища без значних коливань працездатності можливе лише за умов розуміння потреб забезпечення належного рівня здоров'я, що узгоджується зі значенням поняття «здорового способу життя». Відтак, виявлення та пошук потенційних можливостей вирішення проблем, що спіткають сучасних українських студентів вишів на шляху до ведення ЗСЖ залишається актуальним питанням.

Аналіз останніх досліджень i публікацій. Теоретичні основи проблематики ЗСЖ студентів закладів вищої освіти України грунтуються на розвідках українських дослідників останніх років, вибір яких $є$ логічним у відповідності предмету дослідження. Дотичні за суттю дослідження проблематики ЗСЖ студентів було проведене Н. Кетовою, С. Баштан та Т. Шапкіною, висновки яких стали підгрунтям розробки дизайну поточного дослідження. Н. Ковальчук та Е. Довгопол визначили особливості засвоєння студентами положень ЗСЖ. Ю. Бойко запропонувала авторську модель формування мотивації студентів до ЗСЖ, яка містить рекомендації щодо іiі впровадження у освітньому середовищі. В. Колосовська та Т. Лісовенко надали рекомендації, щодо раціональної реалізації напрямів засвоєння студентами основ ЗСЖ в п період навчання у закладах вищої освіти. При визначенні підходів до вирішення проблеми ЗСЖ студентської молоді керувалися результатами дослідження Г. Кондрацької зі співав., а також В. Малашенко, що дало змогу розширити уявлення про предмет дослідження.

Процес формування культури здорового способу життя студентів в освітньому просторі, формування компетентності індивідуального здоров'язбереження проаналізувала Ю. Танасійчук. В свою чергу, у дослідженні С. Цимбалюк розглянуто соціально-культурну складову ЗСЖ студентської молоді. На основі даних вивчених наукових публікацій стало можливим розуміння сутності питання, яке досліджувалося. Також останнє сприяло визначенню актуальної проблематики формування освітнього середовища вищого навчального закладу 3 урахуванням забезпечення засвоєння студентами навичок ЗСЖ.

Мета статті - визначення напрямків формування культури здорового способу життя студентів вищих навальних закладів.

Виклад основного матеріалу. Відповідно до мети статті намагалися розглядати предмет дослідження не 3 позиції наявного стану засвоєння студентами його основ процесу, а саме з точки зору проблем, які заважають їм вести ЗСЖ. Так, студентство можна назвати як категорію людей iз підвищеними факторами ризику [3]. Цими факторами $\epsilon$ : нервове перенапруження та розумова втома, хронічне порушення режиму праці та відпочинку, режиму сну та харчування, шкідливі звички (куріння, вживання спиртних напоїв, наркоманія, захоплення відеоіграми та інтернетом та ін.), недостатня рухова активність, труднощі проживання у гуртожитку та ін.

Скрута сучасного життя залишає мало місця для позитивних емоцій, а отже, щоб задовольнити потреби в позитивних емоціях, студенти намагаються 
їх отримати за допомогою штучних стимуляторів (тютюн, алкоголь, наркотики та ін.), які завдають величезної шкоди здоров'ю організму людини. Наголосимо, що i особи зрілого віку часто користуються даними «інструментами» для полегшення сприйняття оточуючої дійсності.

Сучасні дослідники $[2,3,5,10]$ відзначають, що студентська молодь вдома та у вищих навчальних закладах багато часу проводить у статистичному становищі, це збільшує стомлюваність організму, оскільки навантаження йде на ті самі м'язи. Робота скелетної мускулатури знижується, а це спричиняє порушення постави, викривлення хребта, порушення гнучкості, спритності, швидкості реакції та координації рухів, збільшується шанс розвитку плоскостопості та затримки вікового фізичного розвитку загалом. Це призводить до того, що низька рухливість (гіподинамія) у молодому віці викликає порушення обміну речовин, що сприяє появі зайвої ваги та розвитку ожиріння. Статистичні дані показників здоров'я студентської молоді такі: близько 70\% студентської молоді страждають від наслідків малорухливого способу життя (гіподинамії); від 30\% до 40\% студентів мають надмірну вагу; прояви короткозорості відзначається у 42\% студентської молоді; близько чверті студентів (25\%) страждають від підвищеного артеріального тиску та інших захворювань серцево-судинної системи [4].

Виховання культури ЗСЖ у молодіжному віці - це необхідна умова існування здорової нації, тривалості максимальної трудової та фізичної активності. Проблема формування культури ЗСЖ у студентів вищих навчальних закладах $є$ актуальною, оскільки стан їхнього здоров'я нині - це здоров'я суспільства через 20-30 років. Студентство, будучи особливою соціальною групою, є об'єктом особливої уваги.

Однією $з$ причин несформованої потреби студента вищого навчального закладу у здоровому способі життя, $\epsilon$ те, що педагогічна теорія не дає достатнього уявлення про специфіку, структуру та сутність здорового способу життя учня [1]. Це не повною мірою розкриває можливості освітнього простору щодо формування потреби студентів вищих навчальних закладах у здоровому образі життя.

Початок формування здорового способу життя розпочинається ще в дитячому віці, а в шкільні та студентські роки актуалізується усвідомлення того, що за дотримання принципів здорового способу життя буде легше себе реалізувати у повсякденному житті. Таким чином, здоровий спосіб життя показник, що вказує, як людина реалізує навколишні умови життєдіяльності для свого здоров'я. Формуючи здоровий спосіб життя студентів, необхідно вимагати усвідомленого, активного ставлення студентів до свого здоров'я.

Здоров'я - багатокомпонентне явище, яке має наступні складові:

1. Соматичне здоров'я. Показники поточного стану функціонування всіх органів та систем організму людини. В основу соматичного здоров'я покладено індивідуальну програму біологічного розвитку людини. Вона формується шляхом реалізації базових потреб організму на різних етапах 
онтогенезу. Базові потреби - це основний механізм фізичного розвитку людини, які забезпечують індивідуальність та виступають детермінантом формування соматичного здоров'я.

2. Фізичне здоров'я. Основний компонент у структурі здоров'я людини та іiї стану. Фізичне здоров'я обумовлено біологічними особливостями організму. Без зв'язку різних елементів організму між собою неможливо говорити і про фізичне здоров'я, оскільки окремо існувати та функціонувати якийсь орган (тканини, клітини, органи тощо) не можуть.

3. Психологічне здоров'я. Стан психічної сфери людини, що визначається духовним комфортом. Психологічне здоров'я активізує різні потреби людини, можливостями самореалізації як особистості, тобто. забезпечує соціальне життя людини.

4 Моральне здоров'я. Система цінностей, мотивів, установок, що визначає поведінки людини у суспільстві. Духовність людини є основою морального здоров'я $[8,9]$.

Таким чином, можна виділити складові здорового способу життя [10].

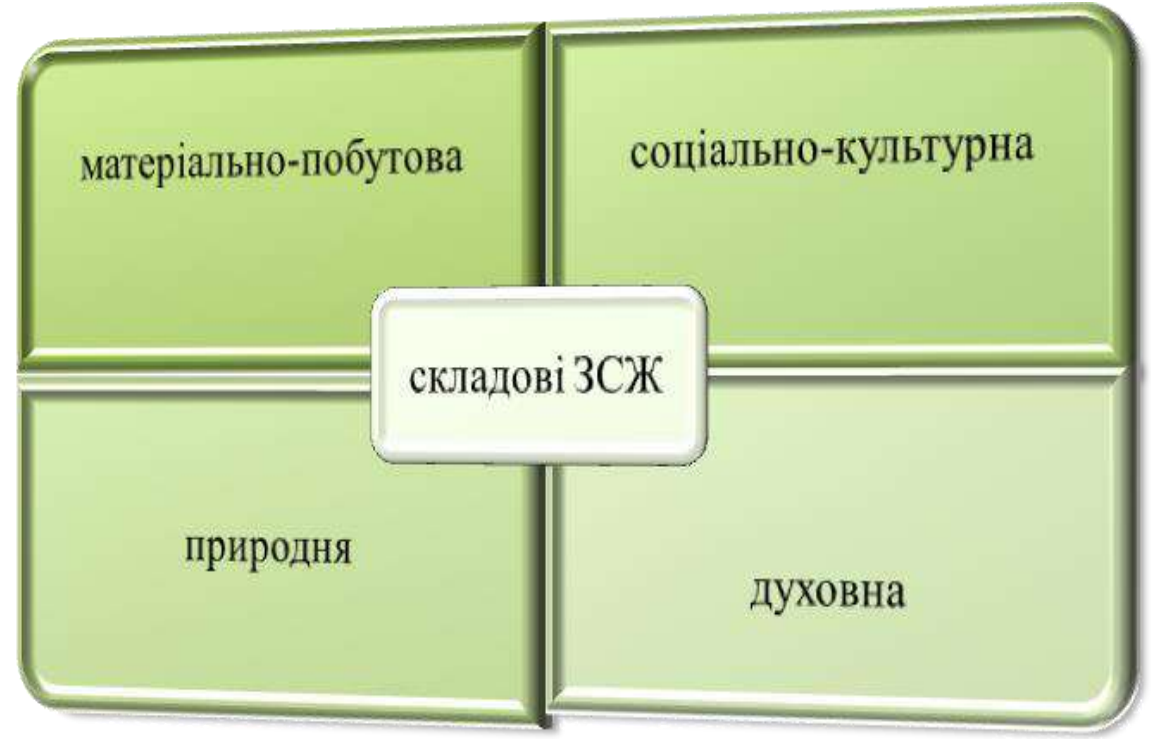

Pис. 1. Складові здорового способу життя

Джерело: складено авторами на основі аналізу [10]

Для визначення проблематики процесу формування навичок здорового способу життя необхідно визначити відношення контингенту, який вивчається до предмету дослідження. Для цього студентам закладів вищої освіти було запропоновано пройти опитування. Розроблені запитання передбачали визначення відношення студентів до здорового способу життя, з одного боку, як до проблеми, а 3 іншого, як до навички яка $\epsilon$ важливою складовою забезпечення якості життя. Варіанти відповідей були однозначними, тому що необхідно було отримати номінальні значення розуміння студентами закладів вищої освіти сутності ЗСЖ (рис. 2). 
У таблиці 1 представлені результати опитування студентів

Таблицуя 1

Опитування студентів щодо відношення до здорового способу життя

\begin{tabular}{|l|r|r|}
\hline \multirow{2}{*}{ запитання } & \multicolumn{2}{|c|}{ Відповіді (\%) } \\
\cline { 2 - 3 } & \multicolumn{1}{|c|}{ Так } & $\mathrm{Hi}$ \\
\hline $\begin{array}{l}\text { Регулярне (мінімум 1 раз/тиж.) вживання тютюну та } \\
\text { алкоголю }\end{array}$ & 60 & 40 \\
\hline Нерегулярне харчування & 65 & 35 \\
\hline Порушення режиму сну & 54 & 46 \\
\hline $\begin{array}{l}\text { Регулярні заняття фізичними вправами (мінімум } 2 \\
\text { рази/тиж.) }\end{array}$ & 52 & 48 \\
\hline Розуміння поняття «здоровий спосіб життя» & 80 & 20 \\
\hline Дотримання режиму дня & 44 & 56 \\
\hline Здоров'я = успішність & 48 & 52 \\
\hline Здоров'я = впевненість & 68 & 32 \\
\hline Здоров'я = духовна рівновага & 81 & 19 \\
\hline
\end{tabular}

Виявлено, що більшість опитаних студентів мають шкідливі звички, що контрастує 3 поняттям «здорового способу життя». Ба більше, понад третина опитаних відзначають, що їх режим харчування характеризується нерегулярністю, половина респондентів, у свою чергу, відзначають порушення режиму сну.

Відповіді на питання іншого блоку доповнюють розуміння та наявність у опитаних студентів культури здорового способу життя. Переважне недотримання режиму дня та часткова участі опитаних у регулярних заняттях фізичними вправами доповнюється тим, що значна кількість респондентів вважають, що розуміють поняття «здоровий спосіб життя».

В той же час, виявлено, що більшість респондентів сприймають власне здоров'я, як фактор особистості і розуміють його переваги, але не вважають його чимось престижним, фактором успішності.

Аналізуючи графіку рисунку 2 необхідно зазначити, що більша частина опитаних респондентів має стійку негативні значення сформованості культури здорового способу життя на тлі переважного розуміння даного поняття. Відтак, отримані дані дають змогу проаналізувати їх з позиції проблематики та культури студентського буття.

Розуміння студентами здорового способу життя на тлі його переважного недотримання більшістю опитаних свідчить про наявність певних культурних обмежень у сприйнятті власного здоров'я як особистісно, так і з точки зору його суспільного значення. Це може свідчити як про низький рівень сформованості культури здорового способу життя, так і про недостатній рівень теоретичних знань щодо ведення ЗСЖ. Відтак, проблемою $\epsilon$ розробка ефективних засобів підвищення рівня обізнаності студентів про ЗСЖ під час навчання у вищих навчальних закладах. 
Журнал«Герспективитаіновації наукиљ

(Серія «Гедагогіка», Серія«ГЕихологія», Серія«Медицина»

№1(6) 2022

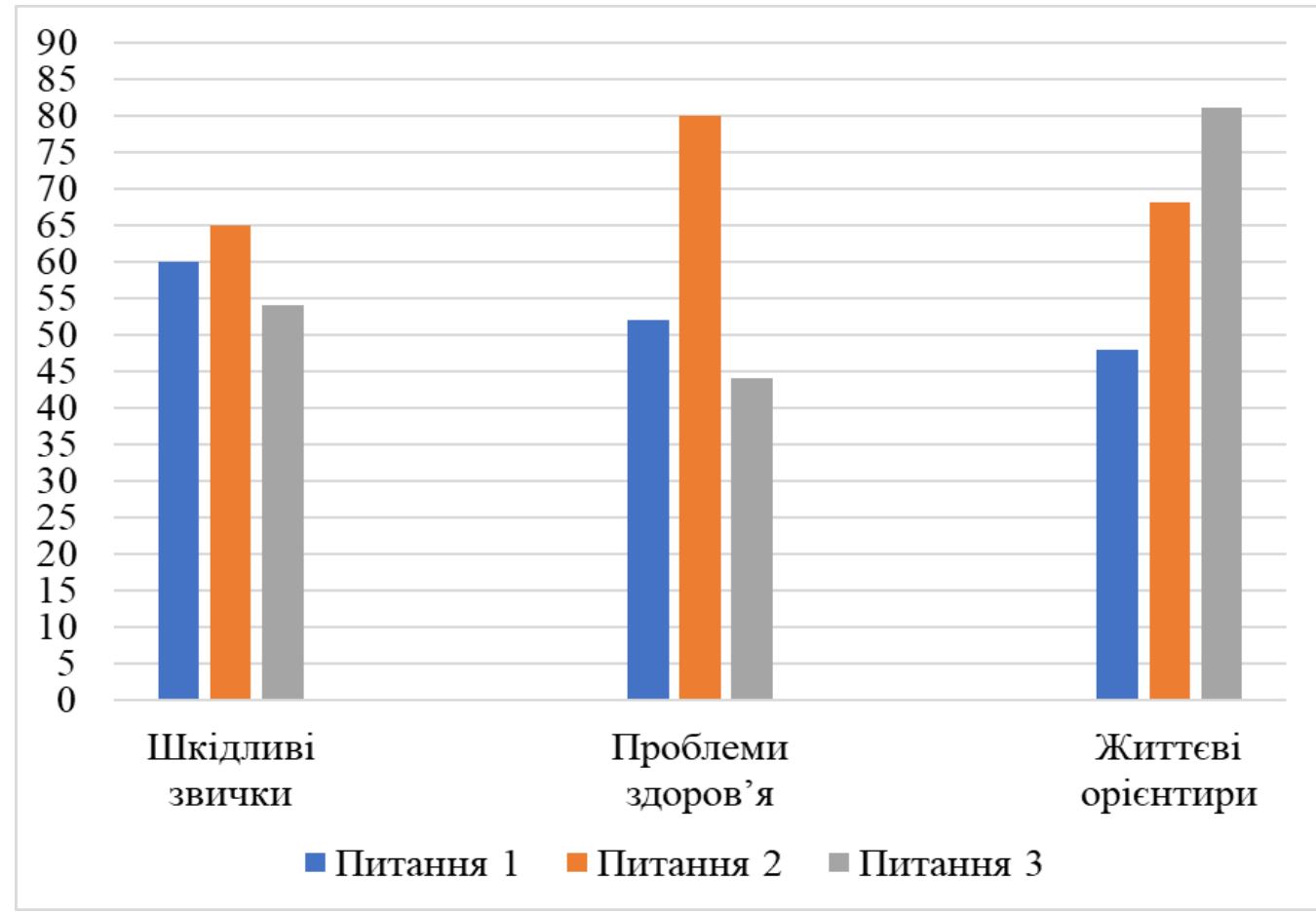

Pис. 2. Відношення студентів до здорового способу життя

Опитування студентів підтвердило існуючі у сучасному суспільстві тенденції зниження рівня культури ЗСЖ через збереження шкідливих звичок у молодіжному (студентському) середовищі і зниження регулярної фізичної активності, яка, вочевидь, обмежується у респондентів лише відвідуванням обов'язкових занять з фізичного виховання. Варто зазначити, що саме такі тенденції фіксують також в осіб середнього віку. Відтак, можна стверджувати про певну «спадковість» поведінки у студентські роки для ведення ЗСЖ у майбутньому. Тому, суттєвою дилемою формування культури здорового способу життя $є$ розробка стратегії пропаганди раціональної рухової активності та профілактики шкідливих звичок, останне має сприяти формування здоров'язбережувального освітнього простору вищих навчальних закладів.

Варто акцентувати увагу також і на позитивних моментах, які мають стати основою формування культури здорового способу життя студентів. Так, необхідно наголошувати, що «кожний юнак самостійно ініціює власну поведінку щодо збереження здоров'я. Цей процес має суто індивідуальний, суб'єктивний характер» [9].

Отже, педагогу необхідно цілеспрямовано створювати умови, що сприяють тому, щоб кожен студент ставав суб'єктом свого розвитку, долучався до здорового способу життя. Інтеграція навчальних дисциплін на створення автономної системи здоров'я забезпечення, моніторинг безперервної освіти стають об’єднуючими прогресивними факторами загальноосвітньої системи, що самоорганізується. Це узгоджуються із розумінням студентів переваг здоров'я для особистості. Однак в той же час 
студенти не ототожнюють здоров’я 3 успішністю, що узгоджується 3 суспільними уявленнями. Відтак, наявною є необхідність вирішення проблеми підвищення престижу поняття «ЗСЖ» не як особистісної характеристики, а як суспільно важливої. Для цього слід, в період навчання у вищих навчальних закладах, здійснювати систематичні пропагандивні заходи, спрямовані на популяризацію культури здорового способу життя.

Таким чином, нині гостро стоїть питання про те, як навчити студентів постійно дбати про своє здоров'я, зацікавити їх регулярно використовувати різні форми та методи ведення ЗСЖ у повсякденному житті. Необхідно, 3 одного боку, створити умови, за яких студенти підвищують та розвивають рівень здоров'я та фізичного розвитку, а 3 іншого, набувають навичок $\mathrm{i}$ отримують знання про основні складові культури ЗСЖ у широкому розумінні.

Процес формування в студентів культури здорового способу життя може складатися з трьох провідних компонентів:

1) інформаційно-пропагандистський компонент формування культури здорового способу життя студентів включає: систему знань та уявлень про форми, способи, методи збереження та зміцнення здоров'я;

2) мотиваційний компонент включає: усвідомлення необхідності ведення ЗСЖ, бажання займатися фізичною культурою і спортом, інтерес до занять фізичною культурою, стійку потребу у веденні ЗСЖ;

3) діяльнісний компонент формування здорового способу життя студентів передбачає: участь у масових фізкультурно-оздоровчих заходах, активні заняття спортом за інтересами, активний відпочинок з урахуванням стану здоров’я та рівнем фізичного розвитку студентів, участь у оздоровчих заходах.

Виділені компоненти процесу формування здорового способу життя студентів взаємопов'язані та взаємообумовлені.

Вченими відзначається слабка мотивація студентської молоді до ведення здорового способу життя, відсутність впровадження у навчально-виховний процес закладів вищої освіти сучасних технологій, спрямованих на збереження та зміцнення здоров'я студентів, формування потреб у ЗСЖ [5, 8, 10]. Формування даної потреби необхідно для того, щоб, починаючи зі студентських років, людина прийшла до усвідомлення необхідності занять фізичною культурою і спортом, мала знання і вміння відновлювати організм після стресових ситуацій i фізичних навантажень. Відтак, можна виділити наступні фактори, що впливають на формування потреби студентів закладів вищої освіти у ЗСЖ $[6,7]$ :

- такі, що сприяють формуванню потреби студентів у здоровому способі життя (пропаганда фізичної культури та спорту через засоби масової інформації; освіта студентів щодо складових ЗСЖ; організація фізкультурнооздоровчої діяльності студентів закладів вищої освітищодо застосування отриманих знань про ЗСЖ у повсякденному житті; індивідуальнодиференційований зміст занять з фізичного виховання у закладів вищої освіти відповідно до стану здоров'я студентів; інтерес до занять фізичною культурою 
та спортом; традиції сім’ї щодо ведення ЗСЖ; рівень професійної майстерності викладачів закладів вищої освіти при реалізації здоров'язберігаючих технологій, наприклад, викладачів у веденні ЗСЖ, бажання бути красивим тощо);

- такі, що перешкоджають формуванню аналізованого процесу (рівень матеріального добробуту сім’ї студентів і традиції способу життя, що склалися в ній; побутові умови; наявність шкідливих звичок, що характеризують спосіб життя і поведінку студентів; думка референтної групи; недостатньо розвинена воля студентів; брак вільного часу; лінь; нерозуміння значимості занять фізичної культури та спорту для здоров’я людини та ін.).

Формування у студентів відповідального ставлення до свого здоров'я та здоров'я оточуючих багато в чому залежить від створення у навчальному закладі організаційно-педагогічних умов, що сприяють формуванню культури здорового способу життя особистості. У системі засобів, що забезпечують процес формування здорового способу життя студентів, провідними виступають такі: профілактика шкідливих звичок молоді, трансляція позитивного впливу на організм здорового способу життя, впровадження сучасних здоров'язберігаючих технологій у навчально-виховний процес вищих навчальних закладів, доступність інформації зі ЗСЖ, включення студентів до масових занять спортом на майданчиках вищих навчальних закладів.

Висновки. Таким чином, сформувати ставлення до культури здорового способу життя як найпершої цінності, дати необхідні для життя кожної людини знання та навчити вести правильний спосіб життя - важливі завдання для студента вищого начального закладу - майбутнього фахівця. Впровадження нових технологій, відповідних форм організації навчальної діяльності та нового іiі змісту мають велике практичне значення для розвитку всебічно розвиненої здорової особистості. Ці завдання можуть бути досягнуті за допомогою розумного поєднання психолого-педагогічного та медикобіологічного підходів, а основною базою для формування культури здоров'я у студентів має стати фізична культура в освітньому середовищі вищого навчального закладу.

Перспективи подальших розвідок у даному напрямі полягають у розробці стратегії та програмних засобів пропаганди здорового способу життя студентської молоді та ऑї «вбудовування»у структуру освітнього середовища як складової різних етапів підготовки майбутнього фахівця.

\section{Лimepamypa:}

1. Баштан С., Шапкіна Т. Проблема формування культури здоров'я студентів у педагогічній теорії. Освітологічний дискурс. 2019. № 3-4 (26-27). С. 61-72.

2. Бойко Ю. Обгрунтування моделі формування аксіологічних установок до здорового способу життя у студентів вищих навчальних закладів. Збірник наукових пращь Уманського державного педагогічного університету імені Павла Тичини. 2017. № 2(1). C. 74-83. 
3. Кетова Н. В. Актуальні проблеми формування здорового способу життя студентської молоді. Науковий часопис НПУ імені М. П. Драгоманова. 2021. Вип. 1 (129). C. 41-44. DOI 10.31392/NPU-nc. series 15.2021.1(129).10.

4. Ковальчук Н. В., Довгопол Е. П. Проблема формування здорового способу життя у студентів вищих навчальних закладів. Науковий часопис НПУ імені М. П. Драгоманова. Серія 15: Науково-педагогічні проблеми фізичної культури (фізична культура $і$ спорт). 2018. № 2. C. 39-41.

5. Колосовська В. В., Лісовенко Т. О. Пріоритетні напрями реалізації фундаментальних принципів здорового способу життя у студентів вищих навчальних закладів. Науковий часопис НПУ імені М. П. Драгоманова. 2019. Вип. 3К (110)19. №15. С. 272-275.

6. Кондрацька Г., Самойлюк С., Максимяк В. Сучасні підходи до формування культури здоров'я студентів. Physical education, sport and health culture in modern society. 2020. №3 (51). С. 3-9.

7. Малашенко В. Теоретичні аспекти формування здорового способу життя студентів вищих закладів освіти. Фізичне виховання, спорт і здоров'я людини: актуальні проблеми та перспективи розвитку. Полтава, 2019. С. 56-59.

8. Нечітайло I. С. Освітній простір вищого навчального закладу: особливості організації з позиції соціології. Вісник Львівського університету. Серія соиіологічна. 2012. Вип. 6. С. 73-80.

9. Танасійчук Ю. М. Формування культури здорового способу життя студентів в освітньому просторі. Формування компетентності індивідуального здоров'язбереження: теорія і практика в освітніх процесах: монографія. Майстерні магістеріуму. Том II. Київ, 2020. С. $42-79$.

10. Цимбалюк С. М. Формування здорового способу життя студентів як складової культури здоров'я. Фізичне виховання, спорт і культура здоров'я у сучасному суспільстві. 2017. № 1 (37). C.106-113.

\section{References:}

1. Bashtan, S. \& Shapkina, T. (2019). Problema formuvannya kul'tury zdorov"ya studentiv $\mathrm{u}$ pedahohichniy teoriyi [The problem of forming a culture of student health in pedagogical theory]. Osvitolohichnyy dyskurs, 3-4 (26-27), 61-72 [in Ukrainian].

2. Boyko, Yu. (2017). Obgruntuvannya modeli formuvannya aksiolohichnykh ustanovok do zdorovoho sposobu zhyttya u studentiv vyshchykh navchal'nykh zakladiv [Substantiation of the model of formation of axiological attitudes to a healthy lifestyle in students of higher educational institutions]. Zbirnyk naukovykh prats' Umans'koho derzhavnoho pedahohichnoho universytetu imeni Pavla Tychyny, 2(1), 74-83 [in Ukrainian].

3. Ketova, N. V. (2021). Aktual'ni problemy formuvannya zdorovoho sposobu zhyttya student's'koyi molodi [Current issues of forming a healthy lifestyle of student youth]. Naukovyy chasopys NPU imeni M. P. Drahomanova, (129), 41-44. DOI 10.31392/NPU-nc. series 15.2021.1(129).10 [in Ukrainian].

4. Koval'chuk, N. V. \& Dovhopol, E. P. Problema formuvannya zdorovoho sposobu zhyttya u studentiv vyshchykh navchal'nykh zakladiv [The problem of forming a healthy lifestyle among students of higher educational institutions]. Naukovyy chasopys NPU imeni M. P. Drahomanova. Seriya 15: Naukovo-pedahohichni problemy fizychnoyi kul'tury (fizychna kul'tura i sport), 2, 39-41 [in Ukrainian].

5. Kolosovs'ka, V. V. \& Lisovenko, T. O. (2019). Priorytetni napryamy realizatsiyi fundamental'nykh pryntsypiv zdorovoho sposobu zhyttya u studentiv vyshchykh navchal'nykh zakladiv [Priority areas of implementation of the fundamental principles of a healthy lifestyle among students of higher educational institutions]. Naukovyy chasopys NPU imeni M. P. Drahomanova, 3K (110)19, 15, 272-275 [in Ukrainian]. 
6. Kondrats'ka, H., Samoylyuk, S. \& Maksymyak, V. (2020). Suchasni pidkhody do formuvannya kul'tury zdorov"ya studentiv [Modern approaches to the formation of student health culture]. Physical education, sport and health culture in modern society, 3 (51), 3-9 [in Ukrainian].

7. Malashenko, V. (2019). Teoretychni aspekty formuvannya zdorovoho sposobu zhyttya studentiv vyshchykh zakladiv osvity [Theoretical aspects of forming a healthy lifestyle of students of higher education]. Fizychne vykhovannya, sport i zdorov'ya lyudyny: aktual'ni problemy ta perspektyvy rozvytku : zb. nauk. prats' studentiv pershoho, druhoho ta tret'oho rivniv vyshchoyi osvity, Poltava, 2019, 56-59 [in Ukrainian].

8. Nechitaylo, I. S. (2012). Osvitniy prostir vyshchoho navchal'noho zakladu: osoblyvosti orhanizatsiyi z pozytsiyi sotsiolohiyi [Educational space of higher education: features of the organization from the standpoint of sociology]. Visnyk L'vivs'koho universytetu. Seriya sotsiolohichna, 6, 73-80 [in Ukrainian].

9. Tanasiychuk, Yu. M. (2020). Formuvannya kul'tury zdorovoho sposobu zhyttya studentiv $v$ osvitn'omu prostori. formuvannya kompetentnosti indyvidual'noho zdorov"yazberezhennya: teoriya i praktyka v osvitnikh protsesakh: monohrafiya [Formation of a culture of healthy lifestyle of students in the educational space. formation of competence of individual health care: theory and practice in educational processes: monograph]. Maysterni mahisteriumu. Tom II. Kyyiv. 42-79 [in Ukrainian].

10. Tsymbalyuk, S. M. (2017). Formuvannya zdorovoho sposobu zhyttya studentiv yak skladovoyi kul'tury zdorov"ya [Creating a healthy lifestyle for students as part of a health culture]. Fizychne vykhovannya, sport $i$ kul'tura zdorov"ya u suchasnomu suspil'stvi : zb. nauk. pr. Skhidnoyevrop. nats. un-tu im. Lesi Ukrayinky, 1 (37), 106-113 [in Ukrainian]. 